\title{
УДК 330.341:640.43(477)
}

\section{СОВРЕМЕННЫЕ ТЕНДЕНЦИИ РАЗВИТИЯ РЕСТОРАННОГО БИЗНЕСА В УКРАИНЕ}

\author{
Воловельская И.В., к.э.н., доцент,
} Лоенко А., магистр (УкрГУЖТ)

Под ресторанным сервисом сейчас понимают не просто «вид услуг», а услуги, приносящие положительные эмоции и чувство удовлетворения не только клиенту (гостю), но и обслужсивающему его персоналу.

Поскольку в отрасли ресторанного бизнеса уже достаточно давно наблюдается совершенствование и изменение форм работы, неизбежно возникают определенные методические сложности в определении тенденций их развития.

В данной статье рассматриваются и анализируются современные тенденции развития ресторанного бизнеса в мире и Украине.

Ключевые слова: ресторан, ресторанный бизнес, тенденции развития.

\section{СУЧАСНІ ТЕНДЕНЦЇ̈ РОЗВИТКУ РЕСТОРАННОГО БІЗНЕСУ В УКРАЇНI}

\author{
Воловельська І.В., к.е.н., доцент, \\ Лоєнко О., магістр (УкрДУЗТ)
}

Під ресторанним сервісом зараз розуміють не просто «вид послуг», а послуги, що приносять позитивні емоиії і почуття задоволення не тільки клієнту (гостю), але $i$ обслуговуючому його персоналу.

Оскільки в галузі ресторанного бізнесу вже досить давно спостерігається вдосконалення $i$ зміна форм роботи, неминуче виникають певні методичні труднощі у визначенні тенденцій їх розвитку.

У даній статті розглядаються та аналізуються сучасні тенденції розвитку ресторанного бізнесу в світі та Україні.

Ключові слова: ресторан, ресторанний бізнес, тенденції розвитку.

\section{MODERN TRENDS IN THE RESTAURANT BUSINESS IN UKRAINE}

\author{
Volovelskaya I.V., Candidate of Economic Sciences, associate professor, \\ Loyenko J., master (UkrSURT)
}

Under a food service now understand not just "service", and services-generating positive emotions and a sense of satisfaction not only to the customer (the guest), and Central office staff.

Because in the industry the restaurant business have long been improving and changing forms of work, inevitably there are certain methodological difficulties in determining the trends of their development.

(С Воловельская И.В., Лоенко А.
Вісник економіки транспорту і промисловості № 55, 2016 
To date, the main tendency of development of restaurant business is the creation of a network and further increase its size. Leader in this field is considered to be America. Their restaurants have a policy of active introduction on markets of all countries of the world. And have the advantage of quick service restaurants with a standard menu.

A distinctive feature of the restaurants on the territory of the former CIS is the preferred position of the elite restaurants in capital cities, associated with higher income levels in these cities.

This article discusses and analyzes modern trends in the restaurant business in the world and Ukraine.

Key words: restaurant, restorani business, trends development.

Постановка

проблемы:

Ресторанный бизнес на сегодняшний день является с одной стороны наиболее прибыльным, a c другой - наиболее рискованным бизнесом в мире. Следует отметить и тот факт, что не существует единой эталонной модели ведения такого бизнеса. Это еще и одна из наиболее инновационных отраслей экономики.

Специфика данного бизнеса, а также недостаточная развитость его в Украине в настоящий момент времени и послужили основой для написания данной статьи.

Анализ последних исследований и публикаций. Вопросами, в которых раскрываются основы ресторанного бизнеса, занимались такие ученые, как: В.В. Архипов, В.А. Русавская, Л. Г. Агафонова, О. С. Агафонова, Т.В. Иванникова, А.В. Архипова и др. $[1,3,4,5,8]$.

Вопросами, технологий ресторанного обслуживания уделили внимание такие учение, как В.И. Богушева, М.И. Белошапка, Е.Н. Артемова., В.А Козлова, и др. [2,6,7,9].

Нерешенные составляющие общей проблемы. Проблема состоит в отсутствии комплексного подхода к исследованию и организации ресторанного бизнеса.

Цель статьи заключается в изучении и анализе современных тенденций развития ресторанного бизнеса в Украине

Изложсение основного материала исследования.

Слово ресторан происходит от латинского restaur, что означает «восстанавливать, реставрировать». Впервые это понятие применил известный кулинар Буланже в начале 18 века: он в своем заведении предлагал бульон как средство для лечения и восстановления «страждущих желудков».

А первые заведения, в которых продавали еду появились в Китае в 6-7 веке, а в Европе - в 11-12 веке.

В развитии заведений ресторанного бизнеса уже достаточно давно наблюдается совершенствование и изменение форм работы. Более того, постоянно находится что-то новое и оригинальное.

Под ресторанным сервисом сейчас понимают не просто «вид услуг», а услуги, приносящие положительные эмоции и чувство удовлетворения не только клиенту (гостю), но и обслуживающему его персоналу.

На сегодняшний день основной тенденцией развития ресторанного бизнеса является создание сети и дальнейшее увеличение ее размеров. Лидером данного направления по праву считается Америка. Их рестораны проводят политику активного внедрения на рынки всех стран мира. Причем преимущество имеют рестораны быстрого обслуживания со стандартным меню: гамбургеры, пицца и др.

Стандартное меню упрощает технологию обслуживания, а также позволяет устанавливать стандартное оборудование во всех ресторанах сети.

Следует отметить и тот факт, что несмотря на кризис в Украине, количество ресторанов в стране неуклонно растет. 
В 2015 году в Украине насчитывается более 15 тыс. коммерческих предприятий общественного питания (кафе, баров, ресторанов). Из них в Киеве находятся около 3 тыс. заведений. Вслед за столицей по уровню развития рынка идет Одесса (около 2 тыс. предприятий). Далее Харьков и др. В общей сложности, по крупным областным центрам количество предприятий составляет 7-8 тыс., то есть около половины всех заведений Украины.

Однако, следует отметить, что ресторанная индустрия в Украине развита неравномерно. Велико различие в развитии между центром и регионами. Более того, отличительной особенностью ресторанов на территории бывшего СНГ является преимущественное расположение элитных ресторанов в столицах и наиболее крупных областных центрах, что связано с более высоким уровнем доходов населения в этих городах.

Далее следует отметить, что большинство рестораторов и экспертов ресторанного бизнеса придерживаются того мнения, что качество и уровень ресторанной культуры в Украине недостаточно высок. Связано это с тем, что большинство заведений уделяют максимум внимания внешним факторам: дизайну интерьера и оформлению подачи блюд, тогда как культура питания практически не учитывается.

Также пользуются популярностью заведения, предоставляющие дополнительные услуги: бассейны, бильярды, караоке и др.

Начинают

популярностью и так называемые рестораны «семейного типа». Эти рестораны выделяются домашней атмосферой, постоянной клиентурой и небольшой территорией. $\mathrm{B}$ таких ресторанах зачастую владелей знает постоянных клиентов и сам принимает заказы или стоит на кухне. В Америке и Европе такие рестораны больше популярны, чем на Украине и это связано еще и с тем, что там их владельцы имеют достаточно большие льготы по налогообложению. В Украине этого нет.

И еще. Хочется все же сказать, что не смотря на кризис, повышение ресторанных цен, сокращение количества заведений, недостаток качества и др, ресторанный бизнес продолжает развиваться. Постоянно открываются рестораны нового формата, предлагаются дополнительные услуги. И это не удивительно, так как наличие пищи основное условие жизни на земле, а вкусная и красиво поданная пища - большое удовольствие, причем, как говорилось выше не только для того, кто ест, но и для того кто готовит и подает.

Bывод: из вышеприведенного анализа можно сделать вывод о том, что такая отрасль народного хозяйства, как общественное питание появилась достаточно давно и развивается достаточно активно. Причем ресторанный бизнес по праву занимает одно из ведущих мест в жизни современного общества, так как наличие пищи является одним из основополагающих условий выживания человечества.

\section{СПИСОК ЛИТЕРАТУРЫ}

1. Агафонова Л.Г. Туризм, гостиничный и ресторанный бизнес: ценообразование, конкуренция, государственное регулирование [Текст]: учеб. пособ. / Л.Г. Агафонова, О.С. Агафонова. - М.: Знание Украины, 2002. $352 \mathrm{c}$.

2. Артемова Е.Н. Основы гостеприимства и туризма [Текст]: учеб. пособ. / Е.Н. Артемова, В.А. Козлова. Орел: Орел ГТУ, 2005. - 104 с.

3. Архипов В.В. Организация ресторанного хозяйства [Текст]: учеб. пособ. / В.В. Архипов. - М.: Центр учебной литературы, 2007. - 280 с.

4. Архипов В.В. Ресторанное дело: ассортимент, технология и управление качеством продукции в 
современном ресторане [Текст]: учеб. пособ. / В.В. Архипов, Т.В. Иванникова, А.В. Архипова. - М.: Фирма "ИНКОС", 2007. - 382 c.

5. Архіпов В.В. Організація обслуговування в закладах ресторанного господарства [Текст]: навч. посіб. для студентів ВНЗ / В.В. Архіпов, В.А. Русавська. - К.: Центр учбової літератури, 2009. $-342 \mathrm{c}$.

6. Белошапка М.И. Технология ресторанного обслуживания [Текст]: учеб. пособ. / М.И. Белошапка. - М: Издательский центр "Академия", 2004. $224 \mathrm{c}$.
7. Богушева В.И. Бары и рестораны. Искусство обслуживания [Текст]: учеб. пособ. / В.И. Богушева. Ростов-на-Дону: Феникс, 2001 - 352 с.

8. Дикань В.Л. Економічна безпека підприємства [Текст]: навч. посіб. для студентів економічних спеціальностей ВН3 / В.Л. Дикань, І.В. Воловельська, О.В. Маковоз. - Х.:УкрДАЗТ, 2011. - 270 c.

9. Dominik P. Zasady i organizacja ywienia w turystyce [Text] / P. Dominik. Warszawa: Almamer, 2011. - 188 p.

Стаття получина: 14.09.162.

\title{
УДК 658.14
}

\section{КАПІТАЛІЗАЦІЯ БАНКІВ ТА НАПРЯМИ ПІДВИЩЕННЯ КАПІТАЛІЗАЦІЇ БАНКІВСЬКИХ УСТАНОВ}

\author{
Зайщева I.Ю., д.е.н., професор, \\ Гутовська А.І., студентка 5 курсу (УкрДУЗТ)
}

У статті розглядаються підходи до визначення сутності $і$ змісту поняття «капіталізація банку», а також трактування изього терміну різними авторами. Розглянуто проблемні аспекти капіталізації банківської системи України та обтрунтовано заходи, щзо сприятимуть підвищенню рівня капіталізащії. Підвищення капіталізаиї вітчизняної банківської системи сприятиме зростанню ї̈ надійності і конкурентоспроможності та, як наслідок, економічній стабілізації в краӥні загалом.

Ключові слова: капіталізація банків, капітал, фінансова стійкість банку, фінансова стабільність банківської системи, ризик.

\section{КАПИТАЛИЗАЦИЯ БАНКОВ И НАПРАВЛЕНИЯ ПОВЫШЕНИЯ КАПИТАЛИЗАЦИИ БАНКОВСКИХ УЧРЕЖДЕНИЙ}

\author{
Зайцева И.Ю., д.э.н., профессор, \\ Гутовская А.И., студентка 5 курса (УкрГУЖТ)
}

В статье рассматриваются подходы к определению сущности и содержания понятия «капитализачия банка», а также трактовка этого термина разными авторами. Рассмотрены проблемные аспекты капитализащии банковской системь Украинь и обосновань мероприятия, способствующие повымению уровня 